\title{
Effect of Growth Hormone on Tubular Transport of Phosphate in Normal and Parathyroidectomized Dogs*
}

\author{
Jacques Corvilain and Maurice Abramow with the technical assistance \\ of A. Bergans \\ (From the Clinique Médicale et Laboratoire de Médecine Expérimentale de l'Hôpital Brug- \\ mann et de la Fondation Médicale Reine Elisabeth, Université Libre de \\ Bruxelles, Belgique)
}

It has been demonstrated recently that human growth hormone $(\mathrm{HGH})$ increases the tubular reabsorption of phosphate in man $(1,2)$. This effect is probably responsible for the fall in urinary excretion of phosphate and the rise in plasma level of phosphorus produced by growth hormone $(\mathrm{GH})$ and may also explain the elevation of plasma phosphorus found in acromegaly.

The action of GH on tubular transport of phosphate is not necessarily a direct one. Since parathormone decreases maximal tubular reabsorption of phosphate $\left(\mathrm{Tm}_{\mathrm{PO}_{4}}\right)$, $\mathrm{GH}$ might affect phosphate reabsorption by inhibiting the secretion of parathormone or by preventing its peripheral action.

Indeed the first of these two hypotheses receives some support from metabolic studies: the enhancement of gastrointestinal absorption of calcium, which may occur during treatment with HGH (3), might be expected to inhibit parathyroid secretion.

The present study has been undertaken to determine whether the action of $\mathrm{GH}$ on tubular transport of phosphate could be explained by a decrease in parathyroid secretion or in parathormone activity. For this purpose $\mathrm{Tm}_{\mathrm{PO}_{4}}$ and the effect of parathormone (PTH) on $\mathrm{Tm}_{\mathrm{PO}_{4}}$ were measured in normal and parathyroidectomized dogs before and after administration of $\mathrm{GH}$.

The results indicate that $\mathrm{GH}$ can increase tubular reabsorption of phosphate in the absence of the parathyroid glands. They show also that GH does not reduce the action of $\mathrm{PTH}$ on the renal tubule.

\footnotetext{
* Submitted for publication February 12, 1964; accepted April 21, 1964.

Reported in part at the Second International Congress of Nephrology, Prague, Czechoslovakia, August 26-29, 1963.
}

\section{Methods}

Female dogs fed constant diets were used for these experiments. Renal studies were performed 22 hours after the last feeding. The dogs were unanesthetized. The bladder was catheterized with a rubber catheter that remained in place throughout the experiment. Five hundred $\mathrm{ml}$ of water was given by stomach tube to increase urine volume. Blood was drawn from an indwelling arterial needle for control blood phosphorus and creatinine. A priming dose of creatinine and phosphate was administered intravenously $(20 \mathrm{ml}$ of a $10 \%$ creatinine solution, $20 \mathrm{ml}$ of a solution containing $\mathrm{Na}_{2} \mathrm{HPO}_{4} \cdot 12$ $\mathrm{H}_{2} \mathrm{O}, 10 \%$, and $\mathrm{KH}_{2} \mathrm{PO}_{4}, 0.75 \%$ ). A sustaining solution containing creatinine and phosphate was then infused at a rate such that a gradual increase of the plasma phosphorus value in the range of 9 to $14 \mathrm{mg}$ per $100 \mathrm{ml}$ was obtained, and serum creatinine value of about 50 to $70 \mathrm{mg}$ per $100 \mathrm{ml}$ was reached.

Thirty minutes after the infusion was begun, urine was collected for consecutive periods varying in length from 10 to 15 minutes. Blood was drawn from the artery at the mid-point of each period. Each collection was ended by washing the bladder twice with distilled water and air.

After five collection periods, $300 \mathrm{U}^{\text {of }} \mathrm{PTH}^{1}$ was injected intravenously.

The infusion of creatinine and phosphorus was maintained, and eight further collections of urine were performed. Three days after such an experiment, intramuscular injections of bovine $\mathrm{GH}^{2}$ were given once a day (1.5 $\mathrm{mg}$ per $\mathrm{kg}$ per day) for 8 days; on day 8 of treatment, the renal study was repeated. The whole set of experiments was done once on four normal dogs and twice on four thyroparathyroidectomized dogs. ${ }^{3}$ In addition, in the normal dog $\mathrm{Ta}$ (experiment $\mathrm{Ta}$ II), the effect of $\mathrm{GH}$ on $\mathrm{Tm}_{\mathrm{PO}_{4}}$ was studied a second time, but in this experiment, PTH was not injected. In the normal $\operatorname{dog} \operatorname{Tr}$ (experiment $\mathrm{Tr}$ II), the effect of PTH on $\mathrm{Tm}_{\mathrm{PO}}$

\footnotetext{
${ }^{1}$ Eli Lilly and Co., Indianapolis, Ind.

2 Generously supplied by the Endocrine Study Section, National Institutes of Health.

3 Results of one set of experiments on thyroparathyroidectomized dog $\mathrm{Po}$ are not included, because in the control study GFR was only $30 \%$ of its normal value.
} 
TABLE I

Effects of growth hormone on renal function and plasma phosphorus in normal dogs*

\begin{tabular}{|c|c|c|c|c|c|c|c|c|}
\hline \multirow[b]{2}{*}{ Dog } & \multicolumn{2}{|c|}{ GFR } & \multicolumn{2}{|c|}{ Tmpo, } & \multicolumn{2}{|c|}{$\frac{\mathrm{TmPO}_{4}}{\mathrm{GFR}} \times 100$} & \multicolumn{2}{|c|}{$\begin{array}{l}\text { Fasting plasma } \\
\text { phosphorus }\end{array}$} \\
\hline & A & B & A & B & A & B & A & B \\
\hline & \multicolumn{2}{|c|}{$m l / \min$} & \multicolumn{2}{|c|}{$m g / m i n$} & & & \multicolumn{2}{|c|}{$m g / 100 \mathrm{ml}$} \\
\hline $\operatorname{Tr} \quad I$ & 31.5 & 47.1 & 1.22 & 2.44 & 3.88 & 5.19 & 2.59 & 4.62 \\
\hline Ta I & 81.4 & 120.3 & 3.19 & 7.01 & 3.92 & 5.83 & 2.47 & 2.68 \\
\hline Ta II & 93.3 & 123.6 & 3.78 & 5.81 & 4.06 & 4.69 & 3.89 & 4.26 \\
\hline $\mathrm{Fr}$ & 54.7 & 69.4 & 1.87 & 3.86 & 3.42 & 5.57 & 2.37 & 3.31 \\
\hline Lo & 91.7 & 107.7 & 4.07 & 5.34 & 4.44 & 4.95 & 3.40 & 3.98 \\
\hline
\end{tabular}

${ }^{*} \mathrm{~A}=$ control values; $\mathrm{B}=$ values after $\mathrm{GH}$ administration. $\mathrm{GFR}=$ glomerular filtration rate. $\mathrm{Tm}_{\mathrm{PO}_{4}}=$ maximal tubular reabsorption of phosphate.

and GFR was measured in a control experiment, but GH was not subsequently administered.

The thyroparathyroidectomized dogs had been operated upon at least 6 weeks previously. The surgical procedure included the complete removal of the thyroid and the associated parathyroids. All dogs had shown severe hypocalcemia after operation, and frequent intravenous injections of calcium were necessary for about 2 weeks to keep them alive. A supplement of calcium was also given in the diet and maintained during the whole study. No thyroid replacement was given. When the GH study began, serum calcium was within the normal limits.

Chemical methods. Creatinine was determined in plasma and urine by the method of Bonsnes and Taussky (4) and inorganic phosphorus by the method of Fiske and SubbaRow (5).

Calculation. Plasma phosphate and creatinine were plotted against times to permit interpolation. The plasma value for a given collection period was assumed to be that 2 minutes before the mid-point.

Clearances of creatinine were calculated in the usual manner. Filtered phosphorus was calculated as the product of creatinine clearance and plasma phosphorus, net reabsorbed phosphorus, as the difference between the filtered and the excreted phosphorus. In each experiment, a maximal tubular reabsorption rate of phosphorus is thought to have been reached; no significant rise in reabsorption rate of phosphorus and in the ratio reabsorption rate of $P / G F R$ was observed when plasma phosphate was elevated in a gradual fashion. The figures for

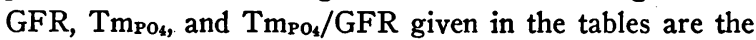
means of five collection periods.

\section{Results}

Control renal function and fasting plasma phosphorus in normal and thyroparathyroidectomized dogs (Tables $I$ and II). The control values of GFR are not significantly different in the two groups.

The means of the control values of $\mathrm{Tm}_{\mathrm{PO}_{4}}$ and $\mathrm{Tm}_{\mathrm{PO}_{4}} / \mathrm{GFR}$ are higher in the parathyroidectomized than in the normal dogs, but the difference is not significant for $\mathrm{Tm}_{\mathrm{PO}_{4}}(0.05<\mathrm{p}<0.1)$. Only the ratio $\mathrm{Tm}_{\mathrm{PO}_{4}} / \mathrm{GFR}$ is significantly higher in the thyroparathyroidectomized dogs $(\mathrm{p}<0.05)$.

Control fasting concentration of phosphate in

TABLE II

Effects of growth hormone on renal function and plasma phosphorus in thyroparathyroidectomized dogs*

\begin{tabular}{|c|c|c|c|c|c|c|c|c|}
\hline \multirow[b]{2}{*}{ Dog } & \multicolumn{2}{|c|}{ GFR } & \multicolumn{2}{|c|}{$\mathrm{TmPO}_{4}$} & \multicolumn{2}{|c|}{$\frac{\mathrm{TmPO4}}{\mathrm{GFR}} \times 100$} & \multicolumn{2}{|c|}{$\begin{array}{c}\text { Fasting plasma } \\
\text { phosphorus }\end{array}$} \\
\hline & A & B & A & B & A & B & A & B \\
\hline & \multicolumn{2}{|c|}{$m l / m i n$} & \multicolumn{2}{|c|}{$m g / \min$} & & & \multicolumn{2}{|c|}{$\mathrm{mg} / 100 \mathrm{ml}$} \\
\hline $\begin{array}{l}\text { St I } \\
\text { St II } \\
\text { Po } \\
\text { Mi I } \\
\text { Mi II } \\
\text { Bo I } \\
\text { Bo II }\end{array}$ & $\begin{array}{l}85.2 \\
72.8 \\
58.1 \\
85.5 \\
60.5 \\
60.7 \\
70.0\end{array}$ & $\begin{array}{r}109.7 \\
90.4 \\
72.9 \\
84.7 \\
64.1 \\
87.2 \\
92.7\end{array}$ & $\begin{array}{l}4.34 \\
5.55 \\
3.45 \\
3.69 \\
2.23 \\
6.69 \\
6.13\end{array}$ & $\begin{array}{l}9.01 \\
7.31 \\
5.15 \\
3.65 \\
2.93 \\
8.48 \\
9.64\end{array}$ & $\begin{array}{l}5.08 \\
7.63 \\
5.92 \\
4.31 \\
3.68 \\
9.46 \\
8.76\end{array}$ & $\begin{array}{r}8.21 \\
8.10 \\
7.05 \\
4.33 \\
4.60 \\
9.74 \\
10.42\end{array}$ & $\begin{array}{l}6.18 \\
4.29 \\
4.57 \\
3.39 \\
5.79 \\
4.70\end{array}$ & $\begin{array}{l}7.73 \\
5.76 \\
4.62 \\
4.10 \\
6.49 \\
5.94\end{array}$ \\
\hline
\end{tabular}

${ }^{*}$ See Table I for explanation. 
TABLE III

Effects of parathyroid extract (PTE) on renal function before and after treatment with growth hormone in normal dogs*

\begin{tabular}{|c|c|c|c|c|c|c|c|c|c|c|c|c|}
\hline \multirow[b]{4}{*}{ Dog } & \multicolumn{6}{|c|}{ Before GH } & \multicolumn{6}{|c|}{ After GH } \\
\hline & \multirow{2}{*}{\multicolumn{2}{|c|}{ GFR }} & \multirow{2}{*}{\multicolumn{2}{|c|}{$\mathrm{TmPO}_{4}$}} & \multirow{2}{*}{\multicolumn{2}{|c|}{$\frac{\mathrm{TmPO}}{\mathrm{GFR}} \times 100$}} & \multirow{2}{*}{\multicolumn{2}{|c|}{ GFR }} & \multirow{2}{*}{\multicolumn{2}{|c|}{$\mathrm{TmPO}_{4}$}} & \multirow{2}{*}{\multicolumn{2}{|c|}{$\frac{\mathrm{TmPO}}{\mathrm{GFR}}$}} \\
\hline & & & & & & & & & & & & \\
\hline & A & B & $\mathrm{A}$ & B & A & B & $\mathrm{A}$ & B & A & B & $A$ & B \\
\hline & \multicolumn{2}{|c|}{$\mathrm{ml} / \mathrm{min}$} & \multicolumn{2}{|c|}{$m g / \min$} & & & \multicolumn{2}{|c|}{$\mathrm{ml} / \mathrm{min}$} & \multicolumn{2}{|c|}{$m g / \min$} & & \\
\hline $\operatorname{Tr} \quad \mathrm{I}$ & 31.5 & 33.9 & 1.22 & 1.15 & 3.88 & 3.38 & 47.1 & 54.6 & 2.44 & 2.55 & 5.19 & 4.68 \\
\hline Tr II & 36.0 & 43.0 & 1.66 & 1.57 & 4.59 & 3.65 & & & & & & \\
\hline $\mathrm{Ta} I$ & 81.4 & 97.2 & 3.19 & 3.32 & 3.92 & 3.42 & 120.3 & 137.8 & 7.01 & 6.77 & 5.83 & 4.89 \\
\hline $\mathrm{Fr}$ & 54.7 & 67.4 & 1.87 & 2.44 & 3.42 & 3.60 & 69.4 & 69.9 & 3.86 & 3.38 & 5.57 & 4.82 \\
\hline Lo & 91.7 & 92.0 & 4.07 & 3.12 & 4.44 & 3.38 & 107.7 & 113.7 & 5.34 & 3.71 & 4.95 & 3.26 \\
\hline
\end{tabular}

${ }^{*} \mathrm{~A}=$ values before PTE administration $; \mathrm{B}=$ values after PTE administration.

the plasma is greater in thyroparathyroidectomized dogs than in normal $(0.02<\mathrm{p}<0.05)$.

Effects of $G H$ on renal function. 1) In normal dogs (Table I) GFR, $\mathrm{Tm}_{\mathrm{PO}_{4}}$, and $\mathrm{Tm}_{\mathrm{PO}_{4}} / \mathrm{GFR}$ increased in the five experiments. 2) In thyroparathyroidectomized dogs (Table II) GFR, $\mathrm{Tm}_{\mathrm{PO}_{4}}$, and $\mathrm{Tm}_{\mathrm{PO}_{4}} / \mathrm{GFR}$ increased in six experiments and did not change in one (Mi I). The increases in GFR, $\mathrm{Tm}_{\mathrm{PO}_{4}}$, and $\mathrm{Tm}_{\mathrm{PO}_{4}} / \mathrm{GFR}$ were all significant at the $1 \%$ level.

Effect of $G H$ on fasting plasma phosphorus (Tables $I$ and $I I$ ). The concentration of phosphorus in the plasma during fasting rose after $\mathrm{GH}$ in all the experiments performed in the two groups of animals. In experiment $\mathrm{Mi} \mathrm{I}$ in which no change in renal function was seen after $G H$, only a very small increase in plasma phosphorus was observed.

Effect of PTH on renal function in normal and thyroparathyroidectomized animals (Tables III and $I V)$. During the first two or three collection periods immediately following $\mathrm{PTH}$ intravenous injection, clearance figures were extremely variable. Sometimes GFR dropped markedly before rising; $\mathrm{Tm}_{\mathrm{PO}_{4}}$ decreased usually from the first post-PTH period.

From the third or fourth to the eighth collection period after PTH, renal function was usually stabilized. Figures from the first three post-PTH periods were discarded, and values of GFR, $\mathrm{Tm}_{\mathrm{PO}_{4}}$, and $\mathrm{Tm}_{\mathrm{PO}_{4}} / \mathrm{GFR}$ after $\mathrm{PTH}$ were calculated as the mean of five collection periods beginning from 40 to 45 minutes after PTH administration.

a) Effect of PTH before GH administration.
In normal dogs (five experiments, Table III), although GFR increased after PTH in all experiments, the increments were sometimes very small. Changes in $\mathrm{Tm}_{\mathrm{PO}_{4}}$ and in $\mathrm{Tm}_{\mathrm{PO}_{4}} / \mathrm{GFR}$ were of questionable significance.

In thyroparathyroidectomized dogs (Table IV), GFR increased in all cases, $\mathrm{Tm}_{\mathrm{PO}_{4}}$ decreased in six out of seven, and $\mathrm{Tm}_{\mathrm{Po}_{4}} / \mathrm{GFR}$ decreased in all seven.

The effect of $\mathrm{PTH}$ on $\mathrm{Tm}_{\mathrm{PO}_{4}} / \mathrm{GFR}$ was significantly greater in thyroparathyroidectomized than in normal dogs $(0.001<\mathrm{p}<0.01)$.

b) Effect of PTH after $G H$ treatment. In normal dogs (four experiments, Table III), after PTH, GFR increased in three experiments and did not change in one. There was a doubtful effect on $\mathrm{Tm}_{\mathrm{PO}_{4}}$. The ratio $\mathrm{Tm}_{\mathrm{PO}_{4}} / \mathrm{GFR}$ was decreased in all four experiments.

In the thyroparathyroidectomized dogs (seven experiments, Table IV), PTH increased GFR in six out of seven experiments and decreased $\mathrm{Tm}_{\mathrm{PO}_{4}}$ in six out of seven and $\mathrm{Tm}_{\mathrm{PO}_{4}} / \mathrm{GFR}$ in all seven.

In the thyroparathyroidectomized group, the drop of $\mathrm{Tm}_{\mathrm{PO}_{4}}$ induced by PTH, expressed in milligrams per minute, was significantly greater after $\mathrm{GH}$ than before $(\mathrm{p}<0.01)$.

\section{Discussion}

In normal dogs, maximal tubular reabsorption of phosphorus was increased 8 days after initiation of bovine growth hormone treatment.

The GFR increased as well, as a result of the well-known effects of $\mathrm{GH}$ on renal hemodynamics (6). The rise in $\mathrm{Tm}_{\mathrm{PO}_{4}}$ was greater than the rise 
in GFR, and the reabsorption of phosphorus per milliliter of filtrate increased. The action of $\mathrm{GH}$ on phosphorus reabsorption thus appears independent of the action on GFR.

An elevation of serum phosphorus was observed on day 8 of $\mathrm{GH}$ administration. The increase in tubular reabsorption of phosphorus per milliliter of filtrate probably is responsible for it.

These data confirm our previous findings obtained on human subjects with HGH (1).

The experiments on thyroparathyroidectomized dogs were performed to exclude the possibility of an indirect action of $\mathrm{GH}$ on tubular phosphate transport through parathyroid inhibition. $\mathrm{GH}$ increased $\mathrm{Tm}_{\mathrm{PO}_{4}}, \mathrm{GFR}$, and $\mathrm{Tm}_{\mathrm{PO}_{4}} / \mathrm{GFR}$ in the thyroparathyroidectomized dogs also, and these effects were of the same magnitude as in normal dogs. Provided that the parathyroid function was entirely and definitively removed by the operation, these results rule out a major intervention of the parathyroid in the action of GH on phosphate tubular transport. Nevertheless, the presence of a residual parathyroid activity cannot completely be excluded. It is well known that after transitory symptoms of parathyroid insufficiency, parathyroidectomized dogs recover after a few weeks a normal blood level of calcium (7) and cannot easily be distinguished from normal with regard to the renal excretion of phosphorus $(8,9)$. The mechanism of the new homeostasis is not known.

Our parathyroidectomized dogs followed the usual pattern. They developed hypocalcemia and tetany after operation, but at the time of the renal studies, the blood calcium was normal, and $\mathrm{Tm}_{\mathrm{PO}_{4}}$ was not significantly higher than normal. They exhibited, however, some signs of parathyroid deprivation: the fasting level of plasma phosphorus and $\mathrm{Tm}_{\mathrm{PO}_{4}} / \mathrm{GFR}$ were higher, and the sensitivity to PTH as measured by a drop in $\mathrm{Tm}_{\mathrm{PO}_{4}} / \mathrm{GFR}$ was greater than in normal controls.

Since the effect of $\mathrm{GH}$ on tubular transport of phosphate has not been found quantitatively different in the normal dogs and in the dogs with parathyroid insufficiency, it is highly improbable that this effect might be mediated by and due solely to parathyroid inhibition.

Although it was demonstrated that $\mathrm{GH}$ could act in the absence of the parathyroids, we found it necessary to investigate whether $\mathrm{GH}$ was able to modify the action of parathormone on the renal tubule.

In the control experiment on normal dogs, acute intravenous administration of $300 \mathrm{U}$ of PTH did not decrease significantly $\mathrm{Tm}_{\mathrm{PO}_{4}}$. These results confirm Hogben and Bollman's findings that intravenous injection of $\mathrm{PTH}$ does not change $\mathrm{Tm}_{\mathrm{PO}_{4}}$ in normal dogs (10).

If we consider the inconstancy of the effect of $\mathrm{PTH}$ in normal dogs, the evaluation of $\mathrm{GH}$ influence on PTH action in this group is pointless.

The parathyroidectomized dogs appeared more sensitive to PTH than normal dogs. In this group intravenous administration of $\mathrm{PTH}$ decreased unequivocally $\mathrm{Tm}_{\mathrm{PO}_{4}}$. These findings confirm Bartter's observation that intravenous PTH decreases phosphorus reabsorption within 1 hour in parathyroidectomized dogs (11) and Lambert, Vanderveiken, De Koster, and Kahn's studies of

TABLE IV

Effects of parathyroid extract on renal function before and after treatment with growth hormone in thyroparathyroidectomized dogs*

\begin{tabular}{|c|c|c|c|c|c|c|c|c|c|c|c|c|}
\hline \multirow[b]{4}{*}{ Dog } & \multicolumn{6}{|c|}{ Before GH } & \multicolumn{6}{|c|}{ After GH } \\
\hline & \multirow{2}{*}{\multicolumn{2}{|c|}{ GFR }} & \multirow{2}{*}{\multicolumn{2}{|c|}{ TmPo4 }} & \multirow{2}{*}{\multicolumn{2}{|c|}{$\frac{\mathrm{TmPO}_{4}}{\mathrm{GFR}} \times 100$}} & \multirow{2}{*}{\multicolumn{2}{|c|}{ GFR }} & \multirow{2}{*}{\multicolumn{2}{|c|}{$\mathrm{TmPO}_{4}$}} & \multirow{2}{*}{\multicolumn{2}{|c|}{$\frac{\mathrm{TmPO}_{4}}{\mathrm{GFR}}$}} \\
\hline & & & & & & & & & & & & \\
\hline & A & B & A & B & A & B & $\mathrm{A}$ & B & $\mathbf{A}$ & B & A & B \\
\hline & \multicolumn{2}{|c|}{$m l / m i n$} & \multicolumn{2}{|c|}{$m g / m i n$} & & & \multicolumn{2}{|c|}{$m l / m i n$} & \multicolumn{2}{|c|}{$m g / \min$} & & \\
\hline St I & 85.2 & 94.7 & 4.34 & 2.27 & 5.08 & 2.39 & 109.7 & 108.6 & 9.01 & 5.63 & 8.21 & 5.18 \\
\hline St II & 72.8 & 82.4 & 5.55 & 4.43 & 7.63 & 5.37 & 90.4 & 102.3 & 7.31 & 5.99 & 8.10 & 5.85 \\
\hline Po & 58.1 & 71.8 & 3.45 & 2.62 & 5.93 & 3.63 & 72.9 & 76.9 & 5.15 & 3.62 & 7.05 & 4.70 \\
\hline $\mathrm{Mi} \quad \mathrm{I}$ & 85.5 & 91.1 & 3.69 & 2.89 & 4.31 & 3.15 & 84.7 & 95.7 & 3.65 & 2.52 & 4.33 & 2.60 \\
\hline Mi II & 60.5 & 76.4 & 2.23 & 2.41 & 3.68 & 3.15 & 64.1 & 83.5 & 2.93 & 2.31 & 4.60 & 2.76 \\
\hline Bo I & 70.7 & 85.3 & 6.69 & 6.07 & 9.46 & 7.12 & 87.2 & 106.7 & 8.48 & 7.46 & 9.74 & 6.99 \\
\hline Bo II & 70.0 & 89.4 & 6.13 & 5.41 & 8.76 & 6.04 & 92.7 & 108.0 & 9.64 & 7.55 & 10.42 & 6.99 \\
\hline
\end{tabular}

* See Table III for explanation. 
the effect of intravenous $\mathrm{PTH}$ on $\mathrm{Tm}_{\mathrm{PO}_{4}}$ in freeflow and stop-flow experiments (12). Similar results have been obtained in normal and hypoparathyroid man under phosphate loading by Hiatt and Thompson (13); in their experiments, in which PTH was given intravenously, the immediate increased phosphaturia observed in normal men was accounted for by a rise in GFR, whereas in the hypoparathyroid subjects, there was in addition a reduction in tubular reabsorption of phosphate.

In the parathyroidectomized group, after $\mathrm{GH}$ administration, the effect of $\mathrm{P} T H$ on phosphate tubular transport, as measured by the absolute drop in $\mathrm{Tm}_{\mathrm{PO}_{4}}$, was greater than in the control experiments. However, the pre-PTH level of $\mathrm{Tm}_{\mathbf{P O}_{4}}$ is always higher after $\mathrm{GH}$ administration than before, as a result of $\mathrm{GH}$ action. The fact that $\mathrm{PTH}$ induces a greater absolute drop in $\mathrm{Tm}_{\mathrm{PO}_{4}}$ after $\mathrm{GH}$ treatment may be thus simply dependent on the difference in the initial level of $\mathrm{Tm}_{\mathbf{P O}_{4}}$. It is at least demonstrated that $\mathrm{GH}$ does not decrease the effect of $\mathrm{PTH}$ on phosphorus reabsorption.

\section{Summary}

In normal dogs, maximal tubular reabsorption of phosphate $\left(\mathrm{Tm}_{\mathrm{PO}_{4}}\right)$, glomerular filtration rate (GFR), and serum level of phosphorus rose after bovine growth hormone $(\mathrm{GH})$ administration for 8 days.

In thyroparathyroidectomized dogs similarly treated with $\mathrm{GH}$, an increase of $\mathrm{Tm}_{\mathrm{PO}_{4}}$, GFR, and serum phosphorus was also observed.

Before GH treatment, acute intravenous administration of parathyroid extract (PTH) decreased $\mathrm{Tm}_{\mathrm{PO}_{4}}$ in thyroparathyroidectomized dogs, but not in normal dogs. On the eighth day of GH administration, $\mathrm{PTH}$ induced in the thyroparathyroidectomized dogs a greater drop of $\mathrm{Tm}_{\mathrm{PO}_{4}}$ than before treatment.

We conclude that the effect of $\mathrm{GH}$ on tubular transport of phosphate is a direct one and cannot be ascribed to parathyroid inhibition or to a decrease of parathormone activity.

\section{References}

1. Corvilain, J., and M. Abramow. Some effects of human growth hormone on renal hemodynamics and on tubular phosphate transport in man. J. clin. Invest. 1962, 41, 1230.

2. Gershberg, H. Metabolic and renotropic effects of human growth hormone in disease. J. clin. Endocr. 1960, 20, 1107.

3. Henneman, P. H., A. P. Forbes, M. Moldawer, E. F. Dempsey, and E. L. Carroll. Effects of human growth hormone in man. J. clin. Invest. 1960, 39, 1223.

4. Bonsnes, R. W., and H. H. Taussky. On the colorimetric determination of creatinine by the Jaffe reaction. J. biol. Chem. 1945, 158, 581.

5. Fiske, C. H., and Y. SubbaRow. The colorimetric determination of phosphorus. J. biol. Chem. 1925, $66,375$.

6. White, H. L., P. Heinbecker, and D. Rolf. Enhancing effects of growth hormone on renal function. Amer. J. Physiol. 1949, 157, 47.

7. Wilson, R. E., R. M. Zollinger, Jr., J. H. Mahan, and J. R. Brooks. Homotransplantation of canine parathyroid tissue in Millipore diffusion chambers. The phenomenon of adaptation to the aparathyroid state. Surg. Forum. 1959, 10, 94.

8. Sanderson, P. H., F. Marshall II, and R. E. Wilson. Calcium and phosphorus homeostasis in the parathyroidectomized dog; evaluation by means of ethylenediamine tetraacetate and calcium tolerance tests. J. clin. Invest. 1960, 39, 662.

9. Bartter, F. C. Personal communication.

10. Hogben, C. A. M., and J. L. Bollman. Renal reabsorption of phosphate: normal and thyroparathyroidectomized dog. Amer. J. Physiol. 1951, 164, 670.

11. Bartter, F. C. The effect of intravenous parathyroid extract on a parathyroidectomized dog in Metabolic Interrelations, Transactions 5th Conference, E. C. Reifenstein, Ed. New York, Josiah Macy, Jr., Foundation, p. 331.

12. Lambert, P. P., F. Vanderveiken, J. P. De Koster, and R. J. Kahn. L'excrétion des phosphates inorganiques et l'action de la parathormone sur le rein. J. Urol. Néphrol. 1962, 68, 481.

13. Hiatt, H. H., and D. D. Thompson. The effects of parathyroid extract on renal function in man. $\mathrm{J}$. clin. Invest. $1957,36,557$. 